\title{
Recognition Code of ZNF191(243-368) and Its Interaction with DNA
}

\author{
Dongxin Zhao $^{1}$ and Zhongxian Huang ${ }^{2}$ \\ ${ }^{1}$ School of Chemistry and Chemical Engineering, Henan University of Technology, Zhengzhou 450001, China \\ ${ }^{2}$ Department of Chemistry, Fudan University, Shanghai 200433, China
}

Correspondence should be addressed to Dongxin Zhao; zhaodx798@163.com

Received 29 May 2015; Accepted 2 September 2015

Academic Editor: Claudio Pettinari

Copyright @ 2015 D. Zhao and Z. Huang. This is an open access article distributed under the Creative Commons Attribution License, which permits unrestricted use, distribution, and reproduction in any medium, provided the original work is properly cited.

ZNF191(243-368) is the C-terminal region of ZNF191 which contains a putative DNA-binding domain of four Cys ${ }_{2} \mathrm{His}_{2}$ zinc finger motifs. In this study, an expression vector of a fusion protein of ZNF191(243-368) with glutathione-S-transferase (GST) was constructed and transformed into Escherichia coli BL21. The fusion protein GST-ZNF191(243-368) was expressed using this vector to investigate the protein-DNA binding reaction through an affinity selection strategy on the basis of the binding quality of the zinc finger domain. Results showed that ZNF191(243-368) can selectively bind with sequences and react with genes which contain an AGGG core. However, the recognition mechanism of $\mathrm{Cys}_{2} \mathrm{His}_{2}$ zinc finger proteins to DNA warrants further investigation.

\section{Introduction}

Krüppel-type $\left(\mathrm{C}_{2} \mathrm{H}_{2}\right)$ zinc finger is ubiquitous motif which mediates the sequence-specific recognition of DNA and widely exists in eukaryotes. This zinc finger protein can also bind DNA, RNA, or other proteins and assume critical roles in various biological functions, including cell differentiation and embryo development [1-3]. Previous studies explored the crystal/NMR structures and DNA-binding sites of zinc finger proteins, and some works reported the possibility of previewing the recognition site of a novel $\mathrm{C}_{2} \mathrm{H}_{2}$ zinc finger protein by sequence analysis [4-7]. However, these observations are insufficient to affirm the recognition code of each amino acid residue $[8,9]$. Thus, obtaining the specific DNAbinding sequences of zinc finger proteins and understanding their functions remain challenging.

In general, the DNA-binding sequence of a novel zinc finger protein with an unknown sequence-specific DNA for recognition can be determined by random oligonucleotide selection or screening from a library of whole genomes [10-12]. However, a great deal of DNA sequences must be determined, and a consensus DNA sequence which is presumed to contact with the typical protein must be provided by computer analysis. Computation results must also be verified by experiments. The results of experiments possibly do not accord with those deduced from amino acid sequences because of the effects of several factors on the recognition code of a zinc finger protein.

The ZNF191 gene is identified from a cDNA library derived from human liver. This gene is located on human chromosome 18q12.1 and is related to a few heredity and tumor diseases [13, 14]. ZNF191 encodes a 368-amino acid protein which includes a putative DNA-binding domain of four $\mathrm{Cys}_{2} \mathrm{His}_{2}$ zinc finger motifs at the C-terminal region. ZNF191(243-368), the zinc finger protein of ZNF191, presumably binds to a specific DNA sequence which acts as the main functional region of ZNF191. Several studies reported on the AT-binding inclination of ZNF191(243-368). However, the actual function and DNA-binding site of ZNF191(243368) remain unclear.

The present study aims to elucidate the function of ZNF191(243-368) at the protein level. We expressed and purified a fusion protein of glutathione-S-transferase (GST) and ZNF191(243-368) and utilized the specific affinity of GST for sepharose 4B resin to select the specific-binding DNA. Results indicated that the consensus binding site of ZNF191(243-368) had an "AGGG" core and implicated that the chemical rules for the sequence-specific recognition of $\mathrm{Cys}_{2} \mathrm{His}_{2}$ to DNA should be used cautiously. 


\section{Materials and Methods}

2.1. Construction of Plasmid for Fusion Protein Expression. A cDNA fragment which encodes the zinc finger region of ZNF191 was subcloned by PCR to create a GST fusion protein. The following oligonucleotide primers (Union Genetic Company, Shanghai, China) were used for PCR and cloning: P1 (5' -CGCGGATCCAGAAATCCCTCTCGAAAGAAACAA- $\left.3^{\prime}\right)$; P2 (5'-TCCCCCGGGTTAAACTTCCACAACATTCAGAAG- $3^{\prime}$ ). The PCR template was pTSA-ZF vector [14]. The ZNF191(243-368) gene was amplified using the upper primer P1 (introduced Bam HI site) and the lower primer P2 (introduced Sma I site). The PCR-amplified fragment and pGEX-4T-2 (Amersham Pharmacia) vector were incubated with Bam HI and Sma I, respectively, purified by an electrophoresis gel, and then mixed and ligated using T4 ligase (BioLabs). The ligation product was transformed into BL21 host strains. The bacterial clone was sequenced, and the recombinant vector was named pGEX-ZF [15].

\subsection{Overproduction and Purification of Zinc Finger Fusion} Protein. LB medium $(50 \mathrm{~mL})$ containing $100 \mu \mathrm{g} / \mathrm{mL}$ ampicillin was inoculated with a single freshly picked colony which contains the expression plasmid pGEX-ZF and then incubated overnight at $37^{\circ} \mathrm{C}$. The overnight culture was diluted 100 times in $500 \mathrm{~mL}$ of $2 \mathrm{YT}$ medium and then grown at $37^{\circ} \mathrm{C}$ to $\mathrm{OD}_{600}=0.6$. Isopropylthio- $\beta$-D-galactoside was then added to a final concentration of $0.5 \mathrm{mM}$, and cells were induced for $3 \mathrm{~h}$ at $30^{\circ} \mathrm{C}$. The cells were harvested by centrifugation $\left(6,000 \mathrm{rpm}\right.$ and $\left.4^{\circ} \mathrm{C}\right)$, resuspended in $100 \mathrm{~mL}$ ice cold PBS (pH 7.4) with $10 \mathrm{mM} \beta$-mercaptoethanol, and then lysed by lysozyme at $4^{\circ} \mathrm{C}$ for approximately $30 \mathrm{~min}$. The mixture was added with $1 \%$ Triton X-100, $1 \mathrm{mM}$ PMSF, and $5 \mathrm{U} / \mathrm{mL}$ DNase I (Sango Company, Shanghai, China) with stirring for $30 \mathrm{~min}$ at $4^{\circ} \mathrm{C}$ to aid protein solubilisation and then centrifuged at $15000 \mathrm{rpm}$ for $30 \mathrm{~min}$ at $4^{\circ} \mathrm{C}$. The supernatant was mixed with $10 \mathrm{~mL}$ of glutathione sepharose $4 \mathrm{~B}$ slurry (Amersham Pharmacia Biotech) and then shaken for $30 \mathrm{~min}$. The affinity matrix was extensively washed with PBS until $\mathrm{OD}_{280}<$ 0.02 , and then GST fusion proteins were eluted in an elution buffer (50 mM Tris, $100 \mathrm{mM}$ reduced glutathione, $\mathrm{pH}$ 8.0). The eluted solution was concentrated using Amicon YM10 (Millipore) and passed through Sephadex G75 column. The purified fusion proteins were mixed with resin for the following binding experiment.

2.3. Zinc Finger Protein-DNA-Binding Assay. Bound DNA of ZNF191(243-368) was obtained using a pool of random oligonucleotides. A 60-base single-strand DNA oligonucleotide which contains a central region of 18 random bases flanked by a 21-base region with defined sequences was synthesized as a template with a sequence of $5^{\prime}$-ATTCAGATCTTAAACACAGGA... $\mathrm{N}^{18}$...GTGATGCTCGGTACCCTAAAG-3'. The following primers were used for PCR: A1 (5'-CGCGGATCCATTCAGATCTTAAACA- $\left.3^{\prime}\right)$ and A2 ( $5^{\prime}$-TTCCCCGGGCTTTAGGGTACCG$\left.3^{\prime}\right)$. A mixture of double-stranded DNA fragments was obtained by Pfu polymerase (BioLabs) through 10 cycles of denaturation $\left(94^{\circ} \mathrm{C}, 1 \mathrm{~min}\right)$, annealing $\left(56^{\circ} \mathrm{C}, 1 \mathrm{~min}\right)$, and extension $\left(72^{\circ} \mathrm{C}, 1 \mathrm{~min}\right)$. The $\mathrm{PCR}$ products were initially treated with phenol/ $\mathrm{CHCl}_{3}$ and then precipitated with ethanol. These DNAs were incubated with GST-ZNF191(243368) fusion proteins bound to glutathione sepharose $4 \mathrm{~B}$ (prepared as previously described) at $4^{\circ} \mathrm{C}$ for $30 \mathrm{~min}$ in binding buffer $[0.2 \mathrm{mg} / \mathrm{mL}$ poly(dI-dC) (Sigma), $0.2 \mathrm{mg} / \mathrm{mL}$ BSA (BioLabs), 25 mM HEPES (pH 7.5), $100 \mathrm{mM} \mathrm{KCl,} 0.1 \mathrm{mM}$ $\mathrm{ZnSO}_{4}, 10 \mathrm{mM} \mathrm{MgCl}_{2}, 0.1 \%$ Nonidet P-40, $1 \mathrm{mM} \mathrm{DTT}$, and $5 \%$ glycerol] [11]. The resin beads were centrifuged and washed four times with binding buffer. The bound oligonucleotides were eluted from beads using the elution buffer and then boiled for 10 min in $\mathrm{H}_{2} \mathrm{O}$. After centrifugation, the supernatant was used for PCR amplification using primers $\mathrm{P} 1$ and P2. After three rounds of selection amplification, the PCR products were digested with Bam HI and Sma I and cloned into pGEX-4T-2 vectors. The recombinant vectors were transformed into Escherichia coli, and the obtained colonies were sequenced.

2.4. UV-Vis Absorption Spectroscopy. The UV spectra of GSTZNF191(243-368) fusion protein, GST, and ZNF191(243-368) were recorded on an HP 8453 Diode Array spectrophotometer (USA). The concentration of the protein solution ( $\mathrm{pH} 7.5)$ with $10 \mathrm{mM}$ Tris- $\mathrm{HCl}$ was detected via Bradford's method, which was $1 \mu \mathrm{mol} \cdot \mathrm{L}^{-1}$.

2.5. Circular Dichroism (CD) Spectroscopy. Circular dichroism spectra of GST-ZNF191(243-368) fusion protein, GST, and ZNF191(243-368) were recorded between 190 and $250 \mathrm{~nm}$ on a J720 Jasco spectropolarimeter. The optical path length was $10 \mathrm{~mm}$, and the concentration of the protein solution (pH 7.5) with $10 \mathrm{mM}$ Tris- $\mathrm{HCl}$ was $1 \mu \mathrm{mol} \cdot \mathrm{L}^{-1}$. The recordings were conducted at $25^{\circ} \mathrm{C}$.

2.6. Fluorescence Measurements. Two synthesized and purified DNA duplexes were used to probe for the DNAbinding activity of ZNF191(243-368) by using fluorescence spectroscopy. One DNA contains the obtained sequence GGAGGGTGGTTA (DNA1), and the other contains the $12 \mathrm{bp}$ motif GAAATAATGTTA (DNA2), as predicted by previous reports [8].

DNA-binding studies were performed in a buffer $(\mathrm{pH} 8.0)$ which contains $50 \mathrm{mM}$ Tris- $\mathrm{HCl}$ and $10 \mathrm{mM} \mathrm{NaCl}$. Titration processes were conducted by adding protein stock solution, GST-ZNF191(243-368), or GST to $1 \mathrm{~mL}$ of a buffer which contains $500 \mathrm{nmol} \cdot \mathrm{L}^{-1}$ of the $12 \mathrm{bp}$ oligonucleotide duplex and $1 \mu \mathrm{mol} \cdot \mathrm{L}^{-1}$ ethidium bromide (EB).

Fluorescence emission spectra were obtained on a Cary Eclipse fluorescence spectrometer (Varian Company) within $550-700 \mathrm{~nm}$ at an excitation wavelength of $540 \mathrm{~nm}$ in a $1 \mathrm{~cm}$ $\times 0.5 \mathrm{~cm}$ fluorescence cuvette at $20^{\circ} \mathrm{C}$. The entrance and exit slits for all fluorescence measurements were maintained at $10 \mathrm{~nm}$.

\section{Results and Discussion}

3.1. Construction of Plasmid and Expression of Fusion Protein. From the DNA sequence of the recombinant plasmid pGEX$\mathrm{ZF}$, the N-terminus of the ZNF191(243-368) gene was linked 
with the C-terminus of the GST gene. Thus, this fusion gene expressed a $40 \mathrm{kDa}$ protein which contains four $\mathrm{C}_{2} \mathrm{H}_{2}$ type tandem zinc finger motifs at the C-terminus of the fusion protein. Bacterially expressed GST-ZNF191(243-368) was purified by glutathione sepharose $4 \mathrm{~B}$ and Sephadex G75 column in accordance with a previously described method. SDS-PAGE analysis of the purified proteins shows a prominent band of the expected size for fusion proteins (Figure 1). After the purified fusion protein was bound to the resin, the mixture was used for the following binding experiment.

3.2. Affinity-Based Selection of DNA-Binding Sites. The predicted structures of four $\mathrm{C}_{2} \mathrm{H}_{2}$ zinc finger domains and gene localisation suggest that ZNF191(243-368) is a DNA-binding protein. To determine the DNA-binding site of ZNF191(243368 ), we used the random oligonucleotide binding selection strategy as previously described. Two affinity processes are involved in the selection procedure, namely, the binding of GST-ZNF191(243-368) to matrix immobilised glutathione sepharose $4 \mathrm{~B}$ and the binding of the random oligonucleotides to the zinc finger protein (Figure 2). A similar binding experiment of the random oligonucleotides to the GST protein was performed as a control.

Based on affinity, we obtained the DNA-binding site of ZNF191(243-368) through a series of washing and amplification processes. We finally transferred these DNA sequences into the pGEX vector and then sequenced this plasmid. DNA sequences which strongly bind to the protein were obtained (Figure 3).

3.3. DNA-Binding Activity. The sequences of the selected DNA-binding sites for GST-ZNF191(243-368) were compared. Among the 69 clones, 38 (55\%) had an AGGG sequence, and similar sequences AGGC, AGGT, and AGGA were present in 7, 4, and 2 clones, respectively. Thus, 51 (74\%) of the resulting clones were discovered to contain an "AGG" core. Although the "AGG" core is outside residual sequences, several sequences have the similar sequences AGCG and ACGG. In addition, the content of GC is high. These results suggest that GST-ZF binds more strongly to the AGGG sequence than to the other sequences.

After comparing these sequences which contain AGGG and computing the probability of bases before and after AGGG, we regarded the binding sequence to be $(G)(G)$ AGGG(G) (Table 1).

The bases of binding sequence were designated 1 through 8 in the binding site column. Comparing these sequences containing AGGG which sometimes appeared two times in a sequence, the number in the bases selected column indicates the frequency of each base that appeared at the 1-8 positions. Each number in the percentage columns indicates the percentage of selected oligonucleotides containing that base at the indicated position.

3.4. Eukaryotic Promoter Database. ZNF191 is widely expressed in human organs and is possibly related to a few hereditary and cancer diseases. Thus, the genes which contain

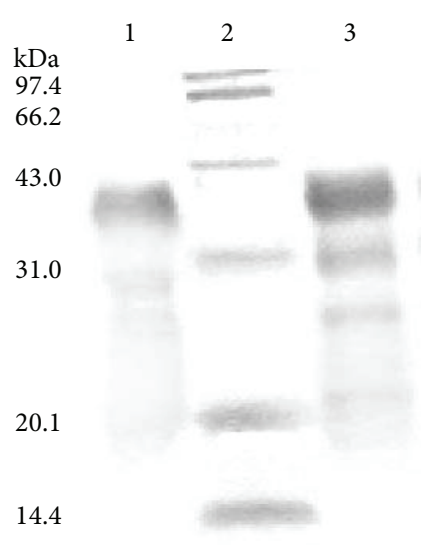

FIGURE 1: SDS-PAGE of GST-ZNF191(243-368) fusion protein. Lane 1: protein purified by $\mathrm{G} 75$, lane 2: protein marker, and lane 3: protein purified by affinity resin.

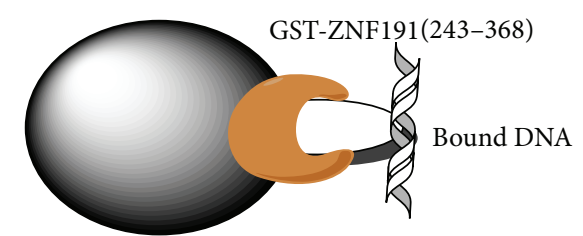

Glutathione sepharose 4B

FIGURE 2: Schematic representation of DNA selecting of GSTZNF191(243-368). Glutathione sepharose 4B is bound by the GST of fusion protein. Meanwhile, the zinc finger protein binds its recognition sequence in DNA and thus immobilizes the DNA on glutathione sepharose 4B.

TABLE 1: Derivation of the ZNF191(243-368) consensus binding site.

\begin{tabular}{|c|c|c|c|c|c|c|c|c|}
\hline \multicolumn{4}{|c|}{ Base selected } & \multicolumn{4}{|c|}{ Percentage (\%) } & \multirow{2}{*}{$\begin{array}{c}\text { Binding site } \\
5^{\prime}-3^{\prime}\end{array}$} \\
\hline G & $\mathrm{C}$ & A & $\mathrm{T}$ & G & $\mathrm{C}$ & A & $\mathrm{T}$ & \\
\hline 20 & 7 & 8 & 9 & 45 & 16 & 18 & 20 & G \\
\hline 24 & 9 & 4 & 7 & 55 & 20 & 9 & 16 & G \\
\hline 0 & 0 & 44 & 0 & 0 & 0 & 100 & 0 & A \\
\hline 44 & 0 & 0 & 0 & 100 & 0 & 0 & 0 & G \\
\hline 44 & 0 & 0 & 0 & 100 & 0 & 0 & 0 & G \\
\hline 44 & 0 & 0 & 0 & 100 & 0 & 0 & 0 & G \\
\hline 23 & 4 & 11 & 6 & 52 & 9 & 25 & 14 & G \\
\hline 14 & 11 & 9 & 10 & 32 & 25 & 20 & 23 & $\mathrm{G} / \mathrm{C} / \mathrm{A} / \mathrm{T}$ \\
\hline
\end{tabular}

the AGGGG core are possibly the target genes of ZNF191(243368). We searched the genes that contain GGAGGGG in the Eukaryotic Promoter Database [16]. Many gene promoters contain this binding site of ZNF191(243-368), such as AHSA1, NOSIP, RHO, and HIVEP2 which relate to metastatic prostate cancer, neuronal NOS activity, denatured states of rhodopsin, and immunodeficiency, respectively [17-20]. Otherwise many chromosome open reading frames, docking proteins, transcription factors, and zinc finger proteins also contain this sequence [21-24]. These indicated ZNF191 widely expressed in human organs possibly related to many physiological processes and diseases. 


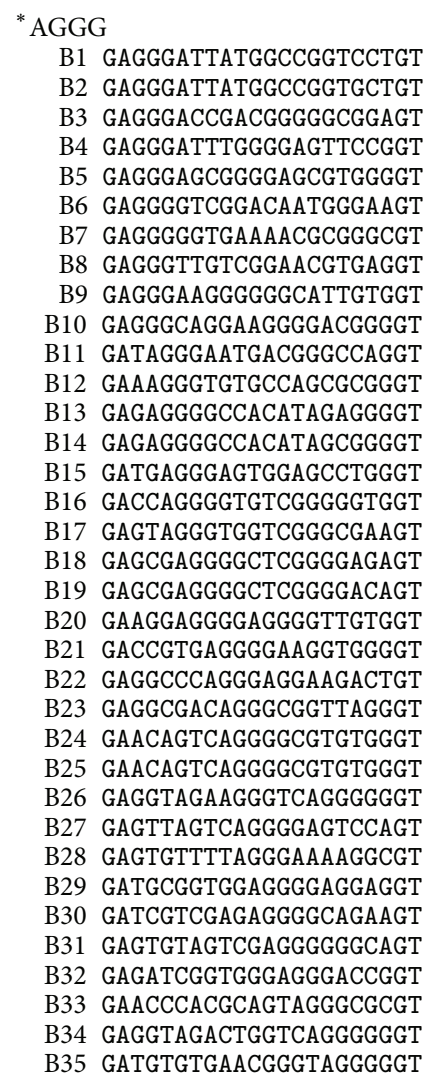

B36 GATAGTAGGATCGGGGAGGGGT

B37 GACATTCTGACCAACCAGGGGT

B38 GACGGTAAACGGGATCTAGGGT

*AGGA, AGGT, AGGC

B39 GAGCGTGGGGTAGGACGCGGGT

B40 GACGATGGAGGATGACGCGAGT

B41 GAAACATAGGACGGAGGCGTGT

B42 GAAGGATTGAGGCATGACTCGT

B43 GAGGACAGGCGGTTGAAAGCGT

B44 GACGATATGCGTGCCGGTAGGT

B45 GAGCGTGAAGCAGGTGCCCAGT

B46 GAAATAAGCTTATTGGGCAGGT

B47 GACAGGCGTTGGGGGCTCAGGT

B48 GAACGAAGGTTCGGGGGTAGGT

B49 GAGGCGGAATGTGTTGGCAGGT

B50 GAACGTGAGGCCGGACACAGGT

* Others

B52 GACTTGGGACTGCGCATCTTGT

B53 GACACGTGGGTGCCGCCAGTGT

B54 GACACGAGTGGGTGAACCGTGT

B55 GATGCCAAGTGAGTGGGAACGT

B56 GAGTGGGGCCGTACCGCGTAGT

B57 GACGCGGGCGCGCAAGTGACGT

B58 GACATGACGGGGGGTTTCCGGT

B59 GAGATCGCGGGGGTATGGGGGT

B60 GATGCCGGGGTGGGGTATTCGT

B61 GAATATTGTCTGCAGAGCGTGT

B62 GACGATGGCAGAAGCGGGCGGT

B63 GACCACGTTTCTCGCAACCAGT

B64 GAGAAAACGAGAAGTGTGTGGT

B65 GACAGCCGCTTAGTGGCGTCGT

B66 GAATGGTACGCTGTGATGCGGT

B67 GAGCTTCGTGTGTGATGCGCGT

B68 GAATGGATGGATCCATGTGTGT

B69 GAGATGACTCTCTACTTGGCGT

FIGURE 3: Alignment of 69 selected oligonucleotides bound to ZNF191(243-368). There are 51 sequences (74\%) containing AGGG motif or similar AGGA, AGGT, AGGC motif, and the content of GC in others is high.

The genes which contain ZF-binding sites possibly react with ZNF191(243-368). Nevertheless, we cannot exclude another possibility that the DNA sequence is not the biological binding site of this protein. Apart from the zinc finger domain of a protein which affects the DNA-binding properties, a few residues outside the zinc finger domain are also involved in the recognition. In addition, the known chemical rules based on the zinc finger motif should be used cautiously. Further studies on the ZNF191 zinc finger protein with DNA are underway.

3.5. UV-Vis Absorption Spectroscopy. The different UV spectrum of the GST-ZNF191(243-368) fusion protein and GST were obtained by subtracting the UV spectrum of GST from that of GST-ZNF191(243-368) (Figure 4). The result indicates that the ZNF191(243-368) in the fusion protein maintains its structure for the absorption of aromatic amino acid residues at $260 \mathrm{~nm}$ to $280 \mathrm{~nm}$ and the absorption of $\mathrm{Zn}-\mathrm{S}$ bond at approximately $230 \mathrm{~nm}[25,26]$. Furthermore, the absorption of several chromophores in GST beyond the linear range cannot be fully deduced from the spectrum, which leads to the significant difference at $200 \mathrm{~nm}$.

3.6. CD Spectral Measurements. The different CD spectrum of GST-ZNF191(243-368) and GST shows that the ZNF191(243-368) in the fusion protein also has two negative peaks at approximately 210 and $220 \mathrm{~nm}$ and a positive peak at approximately $190 \mathrm{~nm}$ of the $\alpha$-helix (Figure 5). Therefore, the ZNF191(243-368) in the fusion protein also maintains a second structure [27-30].

3.7. Binding Constant of Protein-DNA Complexes. Fluorescence spectroscopy is widely used to probe protein-DNA interactions. The binding curves can be generated by titrating the protein solution into DNA solution, and the dissociation constant $\left(K_{d}\right)$ can be obtained by analysing the resulting curve. The addition of EB into the DNA solution enhances the changes in fluorescence intensity.

EB and ZNF191(243-368) compete to bind with DNA in the three-component system on the basis of the Scatchard Equation: $r / c=K(n-r)$ [31-33]. The associations can be described as

$$
\begin{aligned}
& \frac{r_{E}}{c_{E}}=\left(n-r_{E}\right)\left[\frac{K_{E}}{\left(1+K_{P} c_{P}\right)}\right], \\
& \frac{r_{P}}{c_{P}}=\left(n-r_{P}\right)\left[\frac{K_{P}}{\left(1+K_{E} c_{E}\right)}\right],
\end{aligned}
$$

where $r_{E}$ and $r_{P}$ are the ratios of bound EB or protein concentration to the total concentration of DNA; $c_{E}$ and $c_{P}$ are the concentrations of free $\mathrm{EB}$ and protein, respectively; $n$ is the binding number in each oligonucleotide; and $K_{E}$ and 


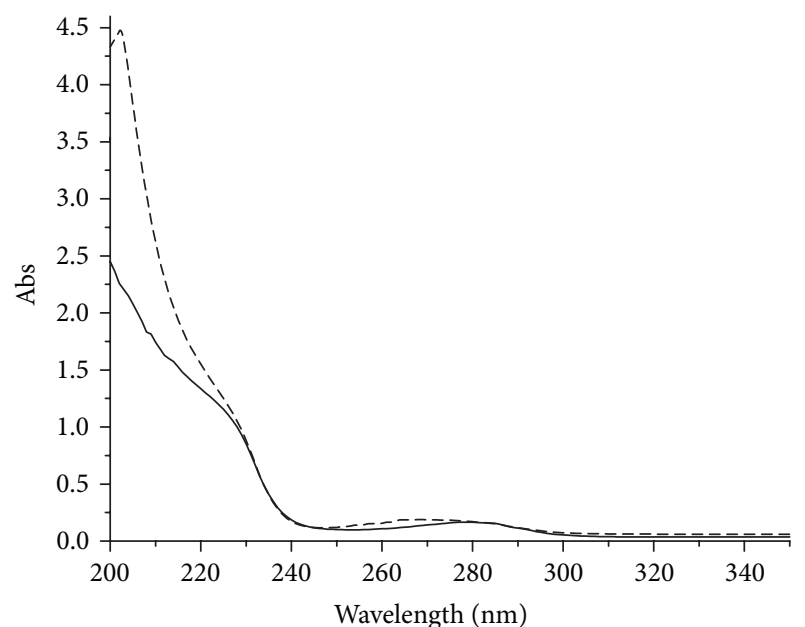

FIGURE 4: Different UV spectrum of GST-ZNF191(243-368) and GST. Solid line is UV spectrum of ZNF191(243-368) and dash line is different UV spectrum of GST-ZNF191(243-368) and GST.

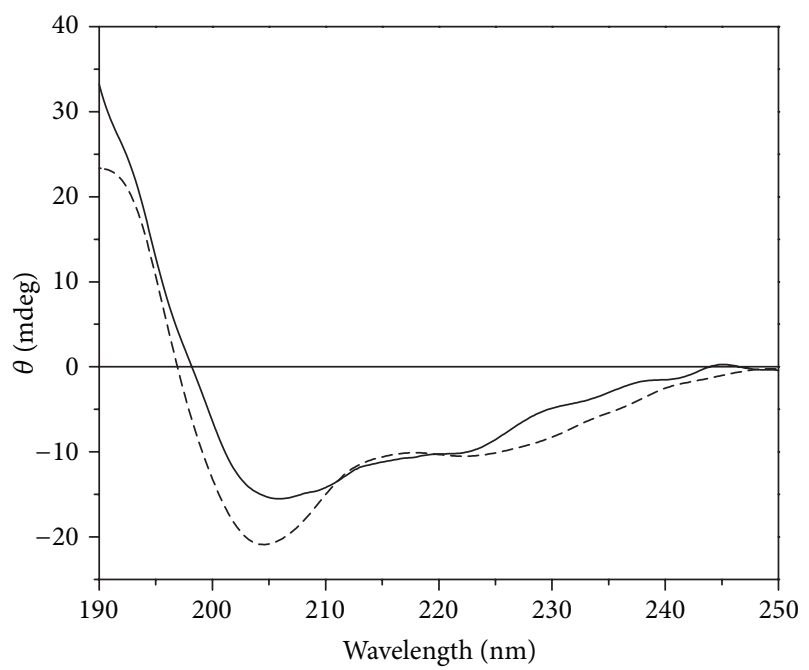

Figure 5: Different CD spectrum of GST-ZNF191(243-368) and GST. Solid line is CD spectrum of ZNF191(243-368) and dash line is different CD spectrum of GST-ZNF191(243-368) and GST.

$K_{P}$ are the association constants of EB and protein with DNA, respectively.

From (1) and (2), (3) can be obtained as follows:

$$
\left(n-r_{E}\right) K_{E}\left(\frac{c_{E}}{r_{E}}\right)-1=r_{P}\left[\frac{\left(1+K_{E} c_{E}\right)}{\left(n-r_{P}\right)}\right]
$$

and $c_{E}=\left[\left(F_{0}-F\right) /\left(F_{0}-F_{\infty}\right)\right] c_{E 0}$, in which $F_{0}$ and $F$ are the fluorescence intensities of the EB-DNA system without and with protein, respectively, and $c_{E 0}$ is the total concentration of $\mathrm{EB}$, which is a known quantity. Thus, only $r_{P}$ is the unknown in (3). Based on the formula $c_{P}=c_{P 0}-r_{P} c_{D 0}$, we can calculate and substitute $r_{P}$ into (2) to obtain the binding constant $K_{P}$ of protein and DNA.

Figure 6 shows the fluorescence spectra of the fusion protein and DNA. In this system, $n$ and $K_{E}$ are 0.2 and

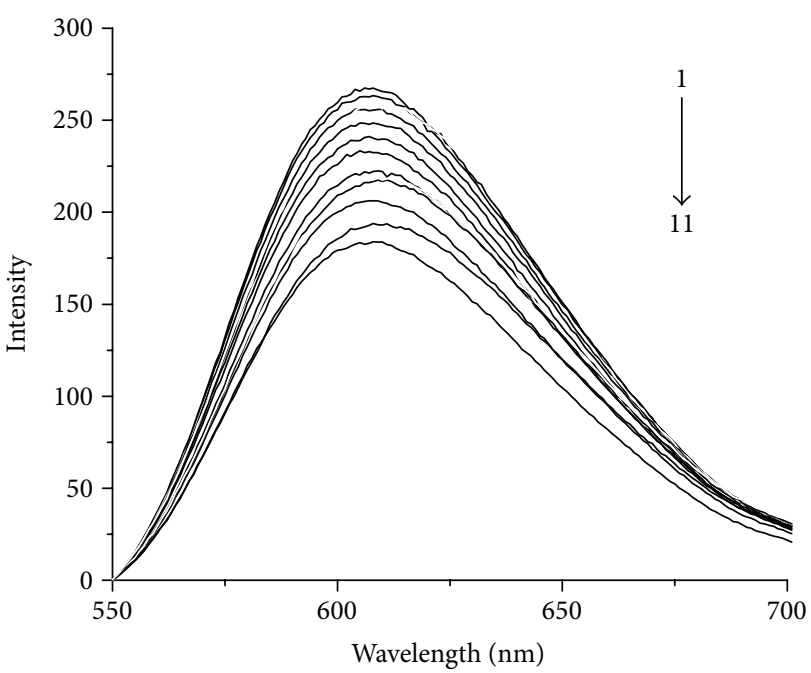

FIGURE 6: Fluorescence spectra of EB-DNA1 titrated by ZNF191(243368). $C_{\mathrm{DNA}}=0.5 \mu \mathrm{mol} \cdot \mathrm{L}^{-1}, C_{\mathrm{EB}}=1 \mu \mathrm{mol} \cdot \mathrm{L}^{-1}$, from up to down, and $C_{\text {protein }} / C_{\mathrm{DNA}}=0,0.1,0.2,0.3,0.4,0.5,0.6,0.7,0.8,0.9,1.0$, respectively.

TABLE 2: The value of $K_{P}$ of ZNF191 (243-368) and DNA.

\begin{tabular}{lc}
\hline & $K_{P}(\mathrm{~L} / \mathrm{mol})$ \\
\hline GST-ZNF191(243-368)/DNA1 & $3.8 \times 10^{7}$ \\
GST-ZNF191(243-368)/DNA2 & $5.4 \times 10^{6}$ \\
I323W $^{\text {a }}$ & $3.2 \times 10^{6}$ \\
R327W $^{\mathrm{a}}$ & $3.6 \times 10^{6}$ \\
\hline
\end{tabular}

${ }^{a}$ Obtained from pTSA/BL21(DE3) system; it is the mutants of ZNF191(243368 ), and used DNA sequence is similar to DNA2.

$5.0 \times 10^{7} \mathrm{~L} \cdot \mathrm{mol}^{-1}$, respectively $[34,35]$. Thus, the association constant $K_{P}$ of GST-ZNF191(243-368) with DNA can be calculated by the equations. The results are shown in Table 2.

The zinc finger protein more strongly binds to DNA1 than to DNA2. In addition, the binding result of DNA2 is close to previous studies, in which two mutant proteins of ZNF191(243-368) were purified from the pTSA/BL21(DE3) system [15]. Thus, the fusion protein can be used to study protein-DNA interactions by the fluorescence method of the three-component system with the highly sensitive and selective EB fluorescence probe. Furthermore, the binding constant between the zinc finger protein and DNA1 obtained from this experiment is $3.8 \times 10^{7} \mathrm{~L} \cdot \mathrm{mol}^{-1}$, which is of nearly one order of magnitude higher than that of the zinc finger protein and DNA2, and very close to those of other zinc finger proteins and DNA $[36,37]$. Therefore, we deduced a strong interaction between ZNF191(243-368) and GGAGGG, which can provide useful information for understanding the function of ZNF191(243-368).

However, this result is different from that reported by $\mathrm{Yu}$ et al. This difference may be attributed to the effects of several factors on the recognition of zinc finger protein to DNA. For example, critical residue(s) in the rest of ZNF191 can induce DNA bending, which facilitates the easy binding of the zinc finger protein [38-40]. The SCAN box 
located before ZNF191(243-368) also has important functions in DNA recognition [41, 42]. Moreover, the cooperative interaction of the various protein components is a factor $[43,44]$.

\section{Conclusion}

ZNF191(243-368) can selectively bind with sequences and react with genes which contain an AGGG core. But the zinc finger domain of a protein is not the only factor which affects DNA-binding properties; some residues outside the zinc finger domain are also involved in the recognition. The known chemical rules based on the sequence of the zinc finger motif should be used cautiously. Further studies on the ZNF191 zinc finger protein with DNA are underway.

\section{Conflict of Interests}

The authors declare that there is no conflict of interests regarding the publication of this paper.

\section{Acknowledgment}

This work was supported by the National Natural Science Foundation of China (no. 21301050).

\section{References}

[1] J. M. Berg and Y. Shi, "The galvanization of biology: a growing appreciation for the roles of zinc," Science, vol. 271, no. 5252, pp. 1081-1085, 1996.

[2] S. V. Razin, V. V. Borunova, O. G. Maksimenko, and O. L. Kantidze, "Cys ${ }_{2}$ his $_{2}$ zinc finger protein family: classification, functions, and major members," Biochemistry, vol. 77, no. 3, pp. 217-226, 2012.

[3] A. Klug, "The discovery of zinc fingers and their development for practical applications in gene regulation and genome manipulation," Quarterly Reviews of Biophysics, vol. 43, no. 1, pp. 1-21, 2010.

[4] H. A. Greisman and C. O. Pabo, "A general strategy for selecting high-affinity zinc finger proteins for diverse DNA target sites," Science, vol. 275, no. 5300, pp. 657-661, 1997.

[5] S. A. Wolfe, L. Nekludova, and C. O. Pabo, "DNA recognition by $\mathrm{Cys}_{2} \mathrm{His}_{2}$ zinc finger proteins," Annual Review of Biophysics and Biomolecular Structure, vol. 29, pp. 183-212, 2000.

[6] R. S. Brown, "Zinc finger proteins: getting a grip on RNA," Current Opinion in Structural Biology, vol. 15, no. 1, pp. 94-98, 2005.

[7] A. A. Rizzo, P. E. Salerno, I. Bezsonova, and D. M. Korzhnev, "NMR structure of the human Rad18 zinc finger in complex with ubiquitin defines a class of UBZ domains in proteins linked to the DNA damage response," Biochemistry, vol. 53, no. 37, pp. 5895-5906, 2014.

[8] J. Zhou, Y. Q. Liu, L. M. Tang, X. C. Teng, N. Tang, and Z. X. Huang, "Fluorescence spectrum of ZNF191(243-368) mutants I323W and R327W with oligonucleotide," Science in China Series B: Chemistry, vol. 46, no. 1, pp. 64-74, 2003.

[9] A. V. Persikov and M. Singh, "De novo prediction of DNAbinding specificities for $\mathrm{Cys}_{2} \mathrm{His}_{2}$ zinc finger proteins," Nucleic Acids Research, vol. 42, no. 1, pp. 97-108, 2014.
[10] A. H. Swirnoff and J. Milbrandt, "DNA-binding specificity of NGFI-A and related zinc finger transcription factors," Molecular and Cellular Biology, vol. 15, no. 4, pp. 2275-2287, 1995.

[11] P. A. Zweidler-Mckay, H. L. Grimes, M. M. Flubacher, and P. N. Tsichlis, "Gfi-1 encodes a nuclear zinc finger protein that binds DNA and functions as a transcriptional repressor," Molecular and Cellular Biology, vol. 16, no. 8, pp. 4024-4034, 1996.

[12] K. W. Kinzler and B. Vogelstein, "The GLI gene encodes a nuclear protein which binds specific sequences in the human genome," Molecular and Cellular Biology, vol. 10, no. 2, pp. 634642, 1990.

[13] G. Y. Liu, S. M. Jiang, C. J. Wang et al., "Zinc finger transcription factor 191, directly binding to $\beta$-catenin promoter, promotes cell proliferation of hepatocellular carcinoma," Hepatology, vol. 55, no. 6, pp. 1830-1839, 2012.

[14] Y. Q. Liu, L. Yu, W. H. Yu et al., "Expression and purification of a novel zinc finger protein," Science in China: Series B, vol. 29, no. 5, pp. 475-480, 1999.

[15] D.-X. Zhao, X.-C. Teng, Z.-C. Ding, and Z.-X. Huang, "Expression and purification of ZNF191(243-368) in three expression systems," Chinese Journal of Chemistry, vol. 25, no. 11, pp. 17391742, 2007.

[16] R. C. Périer, V. Praz, T. Junier, C. Bonnard, and P. Bucher, “The eukaryotic promoter database (EPD)," Nucleic Acids Research, vol. 28, no. 1, pp. 302-303, 2000.

[17] L. Camacho, Ó. Meca-Cortés, J. L. Abad et al., "Acid ceramidase as a therapeutic target in metastatic prostate cancer," Journal of Lipid Research, vol. 54, no. 5, pp. 1207-1220, 2013.

[18] J. Dreyer, M. Schleicher, A. Tappe et al., "Nitric oxide synthase (NOS)-interacting protein interacts with neuronal NOS and regulates its distribution and activity," The Journal of Neuroscience, vol. 24, no. 46, pp. 10454-10465, 2004.

[19] A. Dutta, C. Altenbach, S. Mangahas et al., "Differential dynamics of extracellular and cytoplasmic domains in denatured states of rhodopsin," Biochemistry, vol. 53, no. 46, pp. 7160-7169, 2014.

[20] Y. Wu, H. Gao, H. Li et al., "A meta-analysis of genomewide association studies for adiponectin levels in East Asians identifies a novel locus near WDR11-FGFR2," Human Molecular Genetics, vol. 23, no. 4, pp. 1108-1119, 2014.

[21] R. A. C. van Huet, A. Estrada-Cuzcano, E. Banin et al., "Clinical characteristics of rod and cone photoreceptor dystrophies in patients with mutations in the C8orf37 gene," Investigative Ophthalmology \& Visual Science, vol. 54, no. 7, pp. 4683-4690, 2013.

[22] A. H. Berger, M. Niki, A. Morotti et al., "Identification of DOK genes as lung tumor suppressors," Nature Genetics, vol. 42, no. 3, pp. 216-223, 2010.

[23] T. J. Grant, J. A. Bishop, B. M. Christadore et al., "Antiproliferative small-molecule inhibitors of transcription factor LSF reveal oncogene addiction to LSF in hepatocellular carcinoma," Proceedings of the National Academy of Sciences of the United States of America, vol. 109, no. 12, pp. 4503-4508, 2012.

[24] C. G. Ye, G. G. Chen, R. L. K. Ho, J. L. Merchant, M.-L. He, and P. B. S. Lai, "Epigenetic upregulation of Bak by ZBP-89 inhibits the growth of hepatocellular carcinoma," Biochimica et Biophysica Acta, vol. 1833, no. 12, pp. 2970-2979, 2013.

[25] A. N. Besold, S. J. Lee, S. L. J. Michel, N. L. Sue, and H. J. Cymet, "Functional characterization of iron-substituted neural zinc finger factor 1: metal and DNA binding," Journal of Biological Inorganic Chemistry, vol. 15, no. 4, pp. 583-590, 2010. 
[26] D.-X. Zhao, Z.-C. Ding, Y.-Q. Liu, and Z.-X. Huang, "Overexpression and purification of single zinc finger peptides of human zinc finger protein ZNF191," Protein Expression and Purification, vol. 53, no. 1, pp. 232-237, 2007.

[27] R. Cerpa, F. E. Cohen, and I. D. Kuntz, "Conformational switching in designed peptides: the helix/sheet transition," Folding and Design, vol. 1, no. 2, pp. 91-101, 1996.

[28] D. M. Trindade, J. C. Silva, M. S. Navarro, I. C. Torriani, and J. Kobarg, "Low-resolution structural studies of human Stanniocalcin-1," BMC Structural Biology, vol. 9, article 57, 2009.

[29] Z. Brkljača, K. Čondić-Jurkić, A.-S. Smith, and D. M. Smith, "Calculation of the CD spectrum of a peptide from its conformational phase space: the case of Met-enkephalin and its unnatural analogue," Journal of Chemical Theory and Computation, vol. 8, no. 5, pp. 1694-1705, 2012.

[30] F. R. G. Carneiro, T. C. L. Silva, A. C. Alves, T. Haline-Vaz, F. C. Gozzo, and N. I. T. Zanchin, "Spectroscopic characterization of the tumor antigen NY-REN-21 and identification of heterodimer formation with SCAND1," Biochemical and Biophysical Research Communications, vol. 343, no. 1, pp. 260268, 2006.

[31] J. K. Keppler, M. C. Stuhldreier, F. Temps, and K. Schwarz, "Influence of mathematical models and correction factors on binding results of polyphenols and retinol with $\beta$-lactoglobulin measured with fluorescence quenching," Food Biophysics, vol. 9, no. 2, pp. 158-168, 2014.

[32] T. X. He, Q. L. Liang, T. T. Luo, Y. M. Wang, and G. A. Luo, "Study on interactions of phenolic acid-like drug candidates with bovine serum albumin by capillary electrophoresis and fluorescence spectroscopy," Journal of Solution Chemistry, vol. 39, no. 11, pp. 1653-1664, 2010.

[33] B. Smyk, "Fluorescence study of sinapic acid interaction with bovine serum albumin and egg albumin," Journal of Fluorescence, vol. 13, no. 4, pp. 349-356, 2003.

[34] M. Howe-Grant, K. C. Wu, W. R. Bauer, and S. J. Lippard, "Binding of platinum and palladium metallointercalation reagents and antitumor drugs to closed and open DNAs," Biochemistry, vol. 15, no. 19, pp. 4339-4346, 1976.

[35] Y. Li, Z.-Y. Yang, and M.-F. Wang, "Synthesis, characterization, DNA binding properties, fluorescence studies and antioxidant activity of transition metal complexes with Hesperetin-2hydroxy benzoyl hydrazone," Journal of Fluorescence, vol. 20, no. 4, pp. 891-905, 2010.

[36] J. L. Liu, P. Rigolet, S.-X. Dou, P.-Y. Wang, and X. G. Xi, “The zinc finger motif of Escherichia coli RecQ is implicated in both DNA binding and protein folding," Journal of Biological Chemistry, vol. 279, no. 41, pp. 42794-42802, 2004.

[37] A. Chant, C. M. Kraemer-Pecore, R. Watkin, and G. G. Kneale, "Attachment of a histidine tag to the minimal zinc finger protein of the Aspergillus nidulans gene regulatory protein AreA causes a conformational change at the DNA-binding site," Protein Expression and Purification, vol. 39, no. 2, pp. 152-159, 2005.

[38] M. Nagaoka, W. Nomura, Y. Shiraishi, and Y. Sugiura, "Significant effect of linker sequence on DNA recognition by multi-zinc finger protein," Biochemical and Biophysical Research Communications, vol. 282, no. 4, pp. 1001-1007, 2001.

[39] J. L. Liu, P. Rigolet, S.-X. Dou, P.-Y. Wang, and X. G. Xi, “The zinc finger motif of Escherichia coli RecQ is implicated in both DNA binding and protein folding," The Journal of Biological Chemistry, vol. 279, no. 41, pp. 42794-42802, 2004.

[40] N. Nunez, M. M. K. Clifton, A. P. W. Funnell et al., "The multizinc finger protein ZNF217 contacts DNA through a two-finger domain," The Journal of Biological Chemistry, vol. 286, no. 44, pp. 38190-38201, 2011.

[41] C. Schumacher, H. Wang, C. Honer et al., "The SCAN domain mediates selective oligomerization," Journal of Biological Chemistry, vol. 275, no. 22, pp. 17173-17179, 2000.

[42] Y. Liang, F. Huimei Hong, P. Ganesan et al., "Structural analysis and dimerization profile of the SCAN domain of the pluripotency factor Zfp206," Nucleic Acids Research, vol. 40, no. 17, pp. 8721-8732, 2012.

[43] M. R. Calderon, M. Verway, R. O. Benslama et al., "Liganddependent corepressor contributes to transcriptional repression by $\mathrm{C}_{2} \mathrm{H}_{2}$ zinc-finger transcription factor ZBRK1 through association with KRAB-associated protein-1," Nucleic Acids Research, vol. 42, no. 11, pp. 7012-7027, 2014.

[44] C. Yanover and P. Bradley, "Extensive protein and DNA backbone sampling improves structure-based specificity prediction for $\mathrm{C}_{2} \mathrm{H}_{2}$ zinc fingers," Nucleic Acids Research, vol. 39, no. 11, pp. 4564-4576, 2011. 

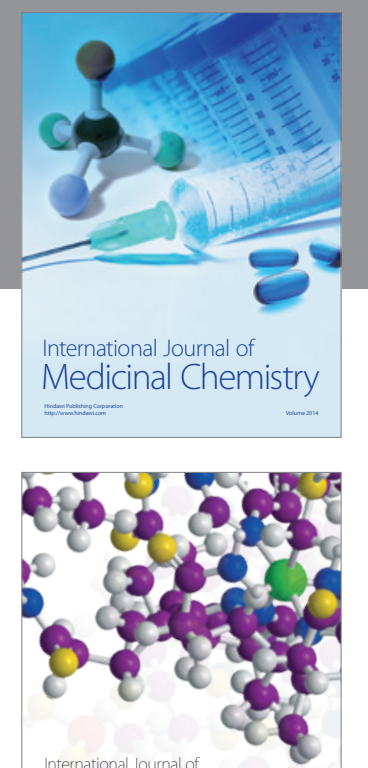

\section{Carbohydrate} Chemistry

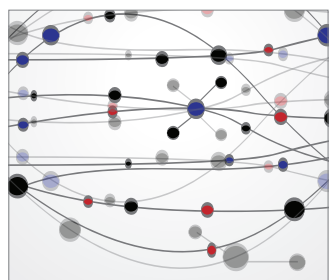

The Scientific World Journal
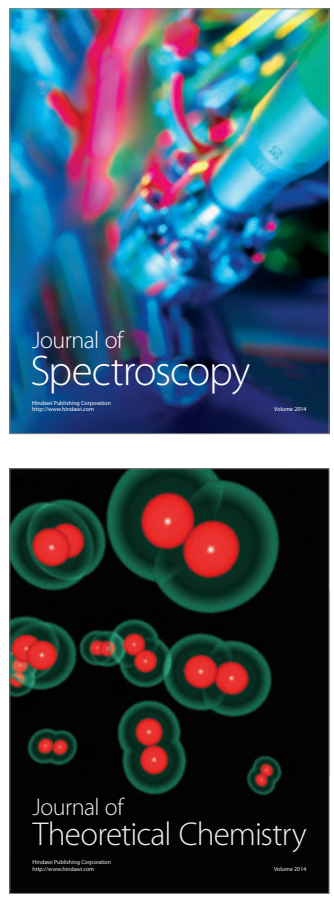
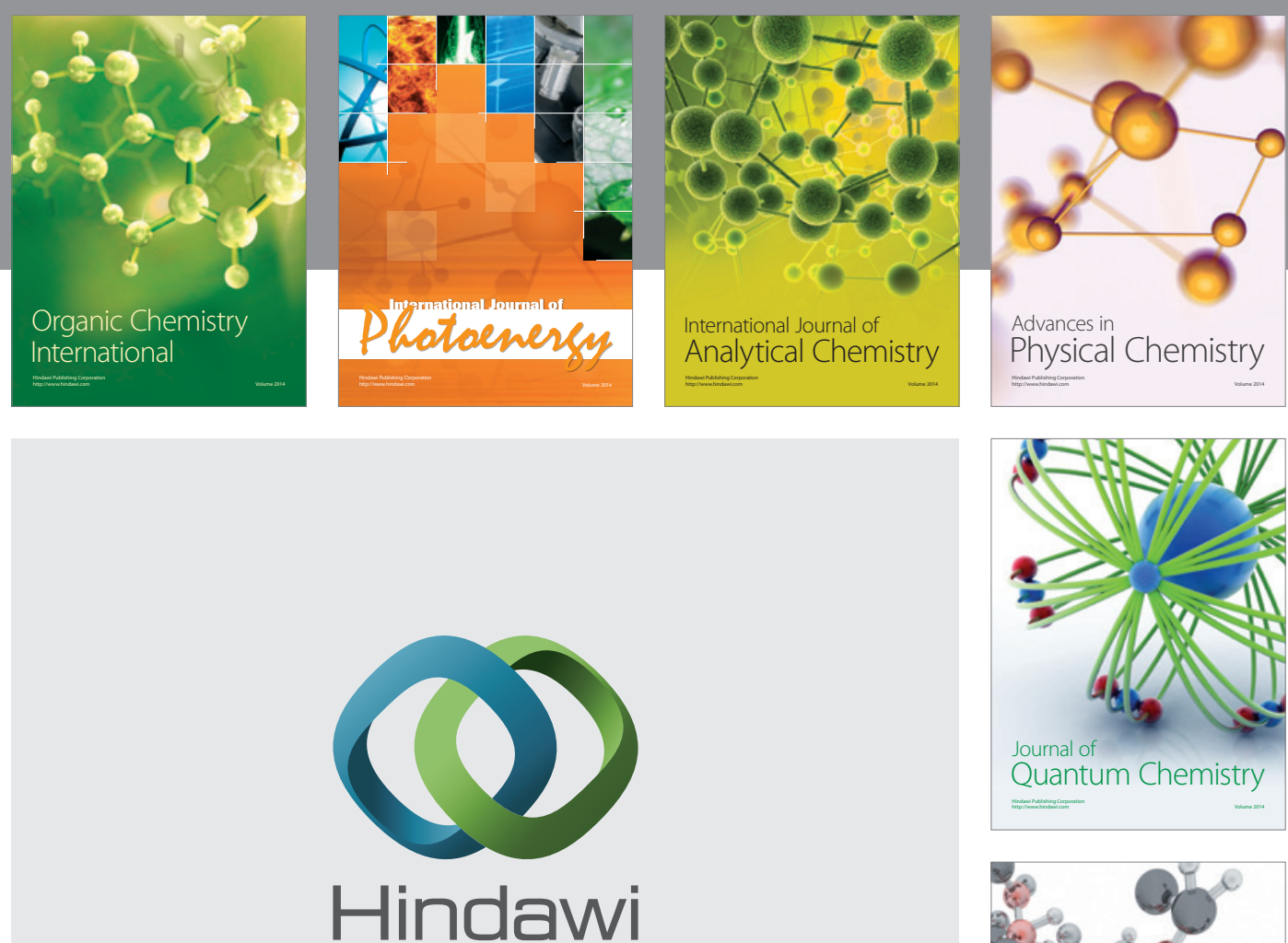

Submit your manuscripts at

http://www.hindawi.com

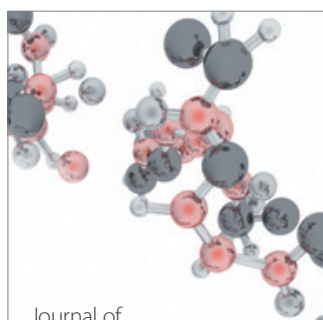

Analytical Methods

in Chemistry

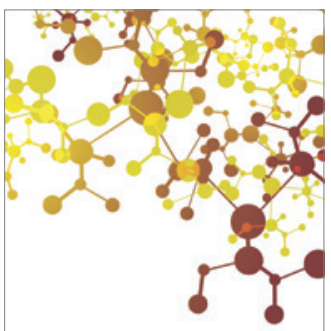

Journal of

Applied Chemistry

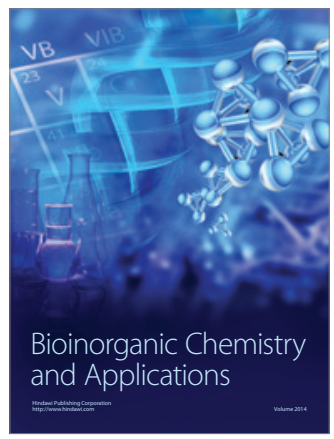

Inorganic Chemistry
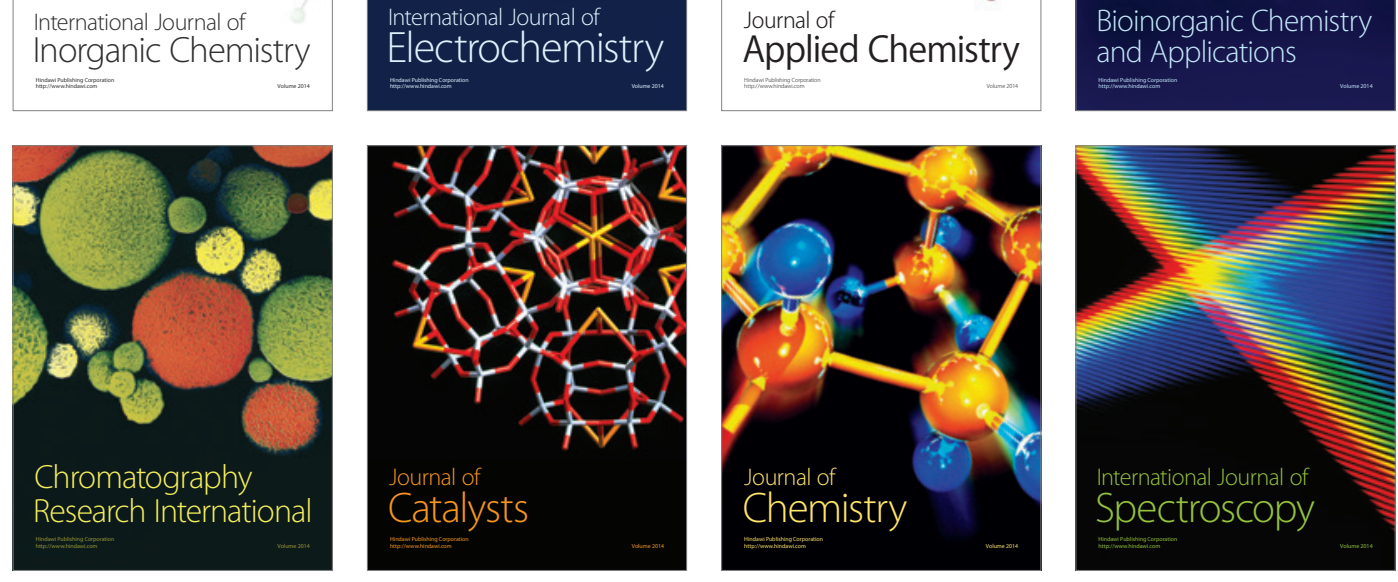